\title{
ANTI-OXIDANT ACTIVITIES OF SOME LESSER KNOWN LEAFY VEGETABLES
}

\author{
By \\ W.M. UDAYANGANI MANI.KE \\ WICKRAMASINGHE
}

M.Sc. 


\section{ANTI-OXIDANT ACTIVITIES OF SOME LESSER KNOWN LEAFY VEGETABLES}

By

W.M. Udayangani Mani ke Wickramasinghe

Thesis submitted to the University of Sri Jaycwardenepura for the award of the Master Degree in Food Science and Technology on $31^{\text {st }}$ march 2006 


\section{DECLARATION}

The work described in this thesis was carried out by me at university of Sri Jayewardenepura under the supervision of Prof. Arthur Bamunuarachchi and Ms. I. Wickramasinghe and a report on this has not been submitted in whole or in part to any University or any other institution for another degree/ diploma.

.2006 .191.1.17...

Date of submission

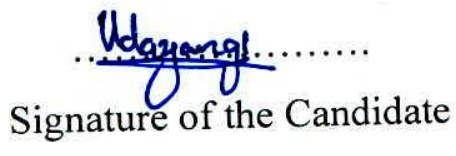




\section{DECLARATION}

"We certify that the above statement made by the candidate is true and that this thesis is suitable for submission to the University for the Purpose of Evaluation".

$2006 / 11 / 17 \ldots$

Date of declaration

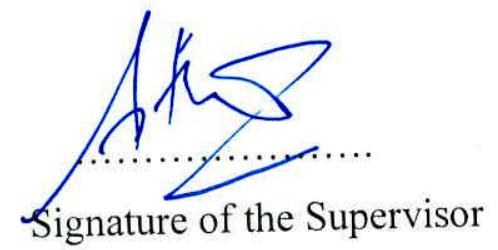

Prof. ArthurBamunuarachchi,

Head Department of Food

Science and Technology,

University of Sri Jayawardenepura,

Nugegoda,

Sri Lanka.

1... $\mid 11.2006$

Date of submission

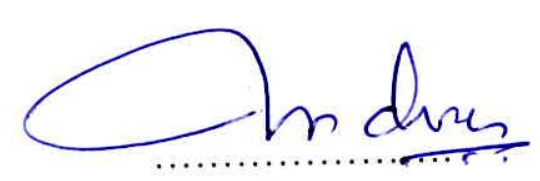

Signature of the Supervisor

Ms.I. Wickramasinghe,

Lecturer,

- Department of Food

Science and Technology,

University of Sri Jayawardenepura,

Nugegoda,

Sri Lanka. 


\section{CONTENTS}

List of tables

vi

List of Figures

vii

List of appendices

vii

Acknowledgement

viii

Abstract

ix

\section{Chapter-1}

1.0. Introduction

\section{Chapter- 11}

2.1 Antioxidants

2.1.1 Definition

2.1.2 Classification of antioxidants

2.1.2.1 According to the origin

2.1.2.1.1. Synthetic antioxidants

2.1.2.1.2. Natural antioxidants

2.1.2.1.2.1. Enzymatic antioxidants

2.1.2.1.2.2. Non-Enzymatic antioxidants.

2.1.2.1.2.2.1 Nutrient antioxidants

2.1.2.1.2.2.2 Non-Nutrient Antioxidants

2.1.2.1.2.2.2.1 Flavonoids

2.1.2.1.2.2.2.2 Carotenoids

2.1.3. Antioxidant functions

2.1.3.1. Enzymatic functions

2.1.3.2. Chemical functions

2.1.3.2.1 Mode of Action of Singlet- Oxygen Quenchers 12

2.1.3.2.2 Mode of Action of Retarders

2.1.3.2.3 Mode of Action of Metal Chelators

2.1.3.2.4 Mode of Action of chains breakers 
2.1.3.2.5 Mode of Action of Synergists

2.2. Applications of Natural Antioxidants 13

2.2.1. Medical applications. 13

2.2.2. Food Applications 14

2.2.3 Antioxidant and aging $\quad 16$

2.3 In Vitro and in Vivo concepts for Antioxidant Methodology 17

2.3.1 Antioxidant methodology in vitro concepts $\quad 17$

$\begin{array}{ll}\text { 2.3.2.1 Antioxidant Methodology in vivo concepts } & 17\end{array}$

2.3.2.2 Defence systems in vivo against oxidative damage 18

2.4 Fish oils 18

2.4.1 Shark Liver Oil 19

2.4.2 Compositions of Shark Liver oil 20

2.4.3 Health benefits of shark liver oil $\quad 20$

2.4.4 Shark Liver oil and Industry 22

2.4.5 Extraction of fish oils. 22

2.4.6 Measure of antioxidant activity 23

2.4.6.1. Spectrophotometric methods 23

2.4.6.1.1 Thiocyanate method 23

2.4.6.1.2. $\mathrm{DPPH}^{+}$free radical scavenging assay 23

2.4.6.1.3. $\mathrm{ABTS}^{+}$Method 24

2.4.6.1.4. 2-Thio Barbituric Acid test (TBA test) 24

2.4.6.2. Spectroscopic methods 24

2.4.6.2.1. Electron Spin Resonance Spectroscopy. (ESR) 24

2.4.6.2.2. IR spectroscopy 24

2.4.6.2.3. Chemiluminescence spectroscopy 24

2.4.6.3. Active oxygen method. (AOM) 24

2.4.6.4. Measure of lipid oxidation $\quad 24$

2.4.6.4.1 Theory of peroxide value (PV) determination 25

2.4.7 Lipid oxidation $\quad 25$

2.5 Determination of vitamin C 26 
2.6 Leaf Vegetables

2.6.1 Red tampala 26

2.6.1.1 Physical Characteristics of Red tampala 27

2.6.1.2 Composition of Red tampala 27

2.6.1.3 Food Uses of Red tampala 27

2.6.1.4 Medicinal Action and Uses of Red tampala 27

2.6.2 Kura tampala 27

2.6.2.1Physical Characteristics of Kura tampala 28

2.6.2.2 Composition of Kura tampala 28

2.6.2.3 Food Uses of Kura tampala 28

2.6.2.4 Medicinal Action and Uses of Kura tampala 28

2.6.3 Penela-wel 29

2.6.3.1 Physical Characteristics of Penela-wel 29

2.6.3.2 Composition of Penela-wel 29

2.6.3.3 Food Uses of Penela-wel 29

2.6.3.4 Medicinal Action and Uses of Penela-wel 30

2.6.4 Agune $\quad 30$

2.6.4.1 Physical Characteristics of Aguna $\quad 30$

2.6.4.2 Composition of Aguna 31

2.6.4.3 Food Uses of Aguna 31

2.6.4.4 Medicinal Action and Uses of Aguna 31

2.6.5 Genda-kola 31

2.6.5.1 Physical Characteristics of Genda-kola 31

2.6.5.2 Composition of Genda-kola $\quad 32$

2.6.5.3 Food Uses of Genda-kola $\quad 32$

2.6.5.4 Medicinal Action and Uses of Genda-kola 32

\section{Chapter -111}

3.1 Estimation of Moisture and Ash Content 33

3.1.1Determination of moisture Content (Wet basis) 33 
3.1.1.1 Materials

3.1.1.2 Method 33

3.1.2 Estimation of Ash Content 34

3.1.2.1 Materials $\quad 34$

3.1.1.2 Method 34

3.2 Preparation of Leaf Vegetabls Samples 35

3.2.1 Preparation of leaf vegetables Extract for evaluation of antioxidant activity 35

3.2.1.1 Materials 35

3.2.1.2 Method 35

3.2.2 Preparation of leaf vegetable Extract for Estimation of constituents 36

3.2.2.1 Materials 36

3.2.2.2 Method $\quad 36$

3.3 Extraction of shark liver oil. $\quad 36$

3.3.1 Materials $\quad 36$

$\begin{array}{ll}\text { 3.3.2. Method } & 37\end{array}$

3.4 Evaluation of Antioxidant Activity of leaf vegetable Samples 38

$\begin{array}{ll}\text { 3.4.1 Materials } & 38\end{array}$

3.4.1.1 Apparatus. $\quad 38$

3.4.1.2 Reagents $\quad 39$

3.4.2 Method $\quad 39$

3.4.2.1 Determination of peroxide value $\quad 40$

3.5 Estimation of Ant oxidative Constituents of leaf vegetable samples $\quad 40$

3.5.1 Tests for tannins and Polyphenols $\quad 40$

$\begin{array}{ll}\text { 3.5.1.1.1 Materials } & 40\end{array}$

3.5.1.1.2 Reagents 41

3.5.1.2 Method 41 
3.5.3.1 Materials

3.5.3.2 Method

3.5.4 Test for Anthraquinones

3.5.4.1 Materials

3.5.4.2 Method

3.5.5 Tests for vitamin C

3.5.5.2 Standard curve

3.5.5.1.1 Materials

3.5.5.1.2 Reagents

3.5.5.1.3 Methods

3.5.5.2 Preparation of the sample

3.5.5.2.1 Materials

3.5.5.2.2 Reagents

\section{Chapter-IV}

4.1 Moisture and Ash content of leaf vegetable samples $\quad 47$

4.1.1 Moisture Contents of leaf vegetable Samples $\quad 47$

4.1.2 Ash Content of leaf vegetable samples $\quad 48$

4.2 Drying time and Storage of Leaf vegetable samples 48

4.3 Recovered percentages and Extractable percentages of Leaf vegetable 49

4.3.1 Recovered percentage high in Agune $\quad 49$

4.3.2 Extractable percentages high in Aguna $\quad 50$ 
4.3.3 Preparation of Leaf vegetable Extract for Estimation of Constituents

4.4 Extractable Percentage of Shark Liver oil

4.5. Antioxidant activity of leaf vegetable samples 52

4.6 Antioxidative Constituents of Leaf Vegetable Samples 57

4.6.1 Tannins and polyphenols presenting leaf vegetable samples $\quad 57$

4.6.2 Flavonoids present in leaf vegetable samples 59

4.6.3 Anthocyanins Present in Leaf vegetable samples $\quad 60$

4.6.3.1 Thin layer Chromatographic analysis of Anthocyanins 61

4.6.4 Anthraquinones Present in Leaf Vegetable samples 62

4.6.5 Vitamin C Content of leaf vegetable 63

4.6.5.1 Standard curve for vitamin C 63

4.6.5.2 Vitamin C content of Leaf Vegetable samples 65

\section{Chapter-V}

5.1 Conclusion $\quad 67$

5.1.1 Moisture and Ash Contents $\quad 67$

5.1.2 Evaluation of Antioxidant activity $\quad 67$

5.1.3 Estimation of chemical constituents $\quad 67$

$\begin{array}{ll}5.2 \text { Further Work } & 68\end{array}$

References $\quad 69-72$

List of Tables

Table 2:1 Type of Antioxidant According to chemical Activity and Their

Chemical Compounds /group

Table 4.1: Moisture and Ash Contents of Leaf vegetable 47

Table 4.2: Drying time of each Leaf vegetable Sample at $50^{\circ} \mathrm{C} \quad 48$

Table 4.3 Extractable Percentages at Different Stages 50 
Table 4.4 Oil percentages in shark livers

Table 4.5 Peroxide Values (PV) of Different treatments with Days at the storage

Temperature of $70^{\circ} \mathrm{C}$

Table 4.6: Results of Test for Tannins and Polyphenols

Table 4.7: the results of Tests for flavonoids

Table 4.8: Characteristic Properties of Flavonoid Classes (Harbone, 1976) 60

Table 4:9 R. f values for Anthocyanins in leaf vegetable

Table 4.10 the results of tests for Anthraquinones in Leaf Vegetable samples62

Table 4.11 Values of Absorbance for Standard curve

Table 4.12 Vitamin C content of Leaf Vegetable samples

\section{List of Figures}

Figure 4.1 The Graph between Peroxide Value (PV) and Storage

Time of Testing

Figure 4.2 Thin Layer Chromatogram of extract Forestal

Figure 4.3 The Graph between Absorbance and weight of ascorbic

acid content

\section{LIST OF APPENDICES}

7.1 Preparation of Solutions

7.1.1 Standardization of sodium thiosulphate solution

7.1.2 Preparation of starch indicator solutions

7.1.3 Preparation of Dye solution

7.1.4 Preparation of Standard Ascorbic Acid Solution

7.1.5 Preparation of 1000-ppm antioxidant solution

7.1.6 Preparation of 1\% Gelatin Solution

7.1.7 Preparation of Gelatin salt Solution

7.1.8 Preparation of Ferric Chloride Test Solution

7.1.9 Preparation of Ammonia test Solution

7.2 Analyzed Data of peroxide Values (PV) of Evaluation of Antioxidant activity 


\section{ACKNOWLEDGEMENT}

This is to express my deep sense of gratitude to all those, who helped me to complete this research project successfully.

First and foremost I wish to express my gratitude to my supervisor Prof. Arthur Bamunuarachchi, Head Department of Food Science and Technology for the advice, guidance and suggestion given by him throughout the project.

I am grateful to Dr. K.K.D.S. Ranaweera; course Coordinator of the M.Sc in Food Science and Technology program, University of Sri Jayewardenepura for directing me to under take my project work at university.

I am greatly indebted to Mr Jagath Wansapala, Ms I. Wickramasinghe, and Ms Rupika Perera of the Department of Food Science and Technology, University of Sri Jayewardenepura for their generous support and guidance to me during working in laboratory.

I also wish to thank $\mathrm{Mr}$ Sisira Weerasinghe, Mr G.P.Rupasinghe of the Department of Food Science and Technology and all members of the laboratory of the chemistry department for their kind cooperation and warm friendship.

I would like to thank Ms M.K.F. Nadheesha of senior batch for guidance extended to me during working in laboratory. I also wish to thank Mr.K.M.D.G.K.B. Kakulandera computer operator and his generous support and helped me to complete this thesis successfully

I would like to take this opportunity to express my sincere thanks to family members of my uncle for providing me accommodation during the M.Sc. Program and their kindness and understanding. Last but not least I am grateful to my family members for their sustained support and encouragement. 


\section{ANTI-OXIDANT ACTIVITIES OF SOME LESSER KNOWN LEAFY VEGETABLES \\ By \\ W.M. Udayangani Manike Wickramasinghe \\ ABSTRACT}

Antioxidants are the chemical species, which has an ability to delay or inhibit oxidations. As People's living condition improves, it is an inevitable tendency that natural antioxidants take the place of synthetic antioxidants. The demand of natural antioxidants will be increased continuously, because of non toxicological effects on animals. Food and medical applications are the major applications of natural antioxidants. Main sources of antioxidants are plants and animals.

The research described in this thesis mainly focuses on evaluation of antioxidant activity of lesser known leafy vegetables (Red tampala: Amaranthus paniculatus, Kura tampala: Amaranthus viridis, Agune: Tinospora malabarica, Penela wel: Cardiospermum microcarpum, Genda kola: Portulaca oleracea. Determination of moisture, ash contents and estimation of chemical constituents, which may possess antioxidant activity of leaf vegetables were also described. Antioxidant activity was evaluated using fish oil modal. Peroxide values (PV) provide information regarding the antioxidant activity of substances. According to the results observed in this study Agune and Genda kola shows the highest antioxidant activity. Lowest antioxidant activity was shown by Kura tampala and Red tampala. Kura tampala show the lowest antioxidant activity and also which is some what similar to synthetic antioxidant BHT. All leaf vegetables had shown chemical constituents polyphenols, Anthraquinones, flavonoids and antocyanins. Red tampala and Genda kola shows the highest and lowest vitamin C. 


\section{CHAPTER-1}

\section{INTRODUCTION}




\subsection{Introduction}

Our bodies naturally protect themselves against free radicals with a class of substances called antioxidants. Their traditional role is, as their name suggests, is inhibiting the development of oxidative rancidity in fat- base foods, practically dairy product, fried food and meat. More recent research has suggested a new role in inhibiting heart disease, hardening of the arthritis, rheumatism, cancer inflammatory condition, cataracts other visual problems and diabetics, etc in the human body. Foods and medicine will be integrated in world marketing the near future. It will undoubtedly increase the demand for natural antioxidants. The interest in using natural substances is mainly due to the toxicity and the low safety coverage of the synthetic antioxidants.

The stabilization of products of vegetable origin against autoxidation is thus less efficient than the stabilization of animal products. Protection factors of comparable antioxidants are several times higher in lard than in edible oils. The initial concentration of natural antioxidants in plant foods is already near the optimum so that a further addition of antioxidants has only a small effect, but it is useful for those cases when rapid decomposition of antioxidants is expected.

The pro- oxidative activity of iron and other heavy metals is less dangerous in plant materials than that of haeme derivatives in animal products, as plant materials usually also contains metal- chelating agents. The only important oxidation catalyst in raw materials and foods of vegetable origin is a group of lipoxygenases and related enzymes.

Over the past fifty years or longer, hundreds of substances derived mostly from vegetable sources have been tested as antioxidants for food lipids. The research reports of related investigations indicate in many instances that such "natural" substances 